\title{
Pathogenic Effects of the Microsporidian Nosema sp., on Larval and Post-cocoon Parameters in Tasar Silkworm, Antheraea mylitta Drury (Daba TV).
}

\author{
G.Renuka and G.Shamitha* \\ Department of Zoology, Kakatiya University, Warangal-506009, Andhra Pradesh
}

\section{Abstract}

The commercial rearing of polyphagous Indian tasar silkworm, Antheraea mylitta Drury being practiced on naturally grown primary food plants like Terminalia arjuna, (Arjun) Terminalia tomentosa (Asan), and Shorea robusta (Sal) available in the tropical forests of central India, at times, is seriously affected by the disease- Pebrine, caused by Nosema sp., a microsporidian pathogen. The present investigation on comparative larval, silk gland weight and also cocoon parameters in Pebrine-free and Pebrine- infected ecorace of tasar silkworm Antheraea mylitta Drury (Daba TV), illustrates the tasar silkworm larvae infected with pebrine disease causing heavy losses to the economy of the silk industry.

Received :

Accepted :

12 Jun 2012

22 February 2013

Keywords:

Antherea mylitta Drury

(Daba TV), Nosema sp., Pathogen, Average larval weight, Silk gland weight, (C) 2013 The Korean Society of Sericultural Sciences Int. J. Indust. Entomol. 26(1), 1-12 (2013)

\section{Introduction}

The tropical tasar culture is an important forest based agro-industry of producing vanya silk by rearing a wild silkworm, Antheraea mylitta Drury (Lepidoptera:Saturniidae), primarily on Terminalia arjuna (arjun), Terminalia tomentosa (asan) and Shorea robusta (sal) and secondarily on Lagerstroemia parviflora, Zizyphus mauritiana, Anogeis suslatifolia, Syzigium cumini, Careya arborea and Hardwickia binata, etc. Tasar Culture is "a forest based industry". It plays a major role in improving socio-economic status of tribal, weaker sections, landless people and women.
The tasar food plant leaf quality in terms of nutrition can influence the health and growth of larvae, effective rate of rearing (ERR) and crop yields as it has correlation with the weights of cocoon, shell and silk ratio and can influence the crop economics. The leaf nutrient status of tasar food plant is fundamental not only for silk productivity, but also for its metamorphosis during life cycle and subsequent parental moth reproductive efficiency. The larval feeding status of any polyphagous commercial insect has impact on food storage and budgeting for biological activities so as to combat the adverse or to excel during favorable conditions (Reddy et al., January 2012).

The diseases in silkworm are the major constraints

\section{*Correspondence :}

G.Shamitha

Department of Zoology, Kakatiya University, Warangal-506009, Andhra Pradesh

Tel: +91 9866010003 / FAX: +0870-2578044

E-mail: vodithalashamitha@gmail.com

http://dx.doi.org/10.7852/ijie.2013.26.1.001

(C) 2013 The Korean Society of Sericultural Sciences 


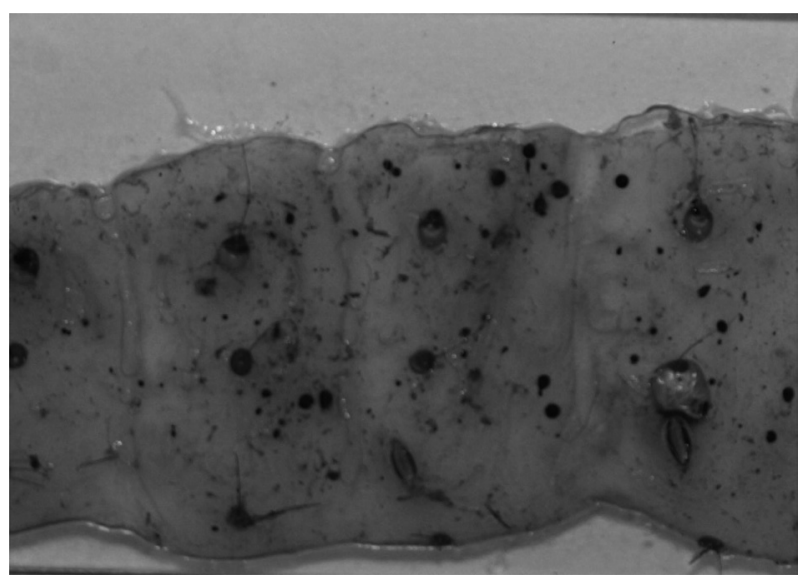

Fig. 1. The integument of Tasar silkworm, Antheraea mylitta $\mathrm{D}(\mathrm{Daba} \mathrm{TV})$ showing black spots.

in tasar culture, which adversely affect the economics of this culture by causing $35-40 \%$ crop loss. Among the diseases, pebrine is causing most devastating effect on the rearing of the tasar silkworm accounts for 20-25\% yield loss (Sahay et al., 2000). Even though some work has been done on the breeding aspects of Tasar silkworm, not much work has been published so far on pathological aspects of tasar silkworm (Reddy et al., 2010).

Tasar silkworm is often infected with the intracellular parasite of the genus Nosema. Pebrine can be acquired from the mother moth (primary infection) or from the environment through food (secondary infection). Infected larvae show black pepper like spots on the integument. These infected hypodermal cells become enlarged and vacuolated and blackened due to the formation of melanin (Ganga, 2003). Larvae infected with Nosema sp. show extended development period, reduced size and larval weight in comparison to uninfected ones (Rath et al., 2003).

Pebrine is a disease caused in tasar silkworms, by a parasitic microsporidian-Nosema mylittensis, belonging to the family Nosematidae, Genus -Nosema, Species -mylettensis ; affected by which, the larvae show slow growth, undersized body and poor appetite. Diseased larvae reveal pale and flaccid body. Tiny black spots appear on larval integument (Fig. 1). Dead larvae remain rubbery and do not undergo putrefaction shortly after death. The pathogen comes from infected

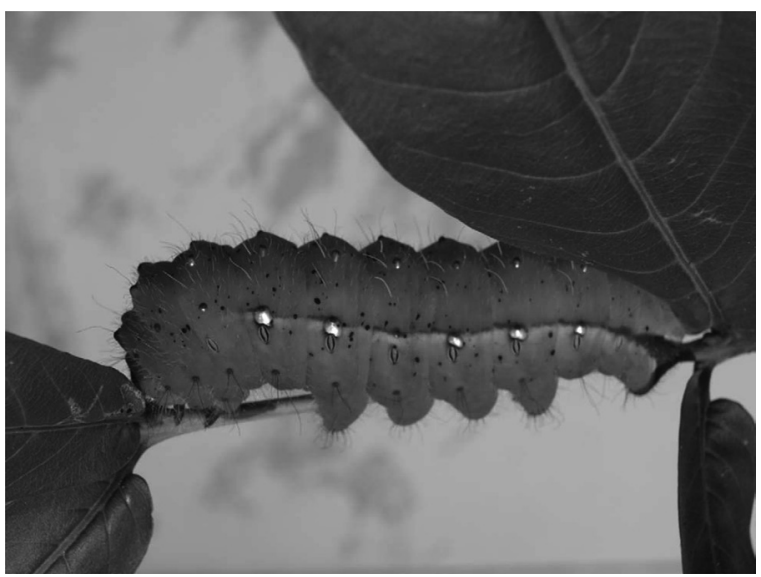

Fig. 2. ThePebrine infected tasar silkworm, Antheraeamylitta. D (Daba TV).

eggs laid by infected mother moths or exists in rearing facilities as spores or come from wild insects naturally infected (Fig. 2) with Nosema mylittensis.

This dreaded disease is also known as pepper disease or corpuscle. The name pebrine was given to the disease in 1860 by De Quatrefages because the black spots that appear on the diseased silkworms look like pepper grains. The disease was not properly understood until the researches of Louis Pasteur during the years 1865-70 brought out a method of diagnosis. Pasteur established that the disease invariably manifests itself in the mother moth though sometimes it may not be possible to detect it in the larval and cocoon / pupal stages (Fig. 3 and 4).

There are two stages in the life cycle of this organism, the spore stage and the vegetative stage. The mature spore is oval and measures 3-4 microns by 1.5-2 microns. The spore consists of spore membrane, which encloses the sporoplasm, in the form of girdle across the width of the spore, anterior and posterior vacuoles, two nuclei in the sporoplasm and polar capsule which encloses a spiral polar filament (30 times the length of the spore) which is projected through the small opening. The pathogen comes from infected eggs laid by infected mother moths. It may also exist in rearing facilities or $T$. arjuna garden as spores.

During the vegetative stage the $T$. arjuna leaf acts as a means of transmission, to which the spores stick and enter along with the leaves, which are ingested by the 


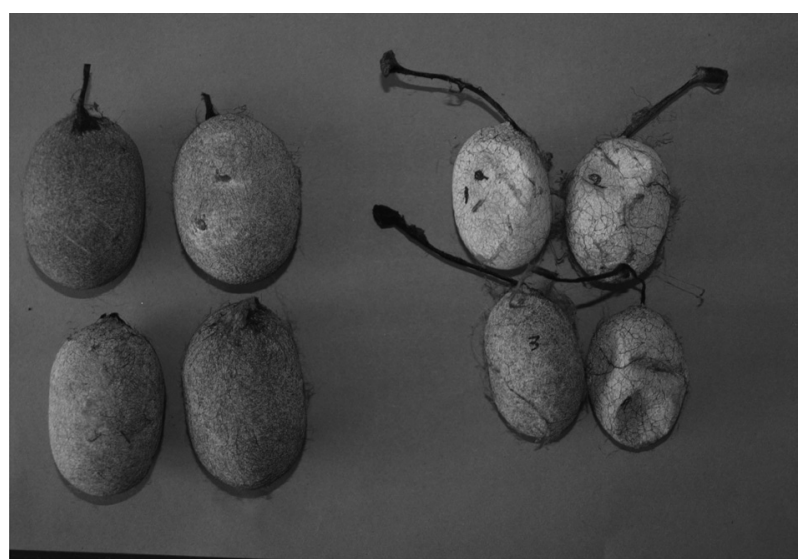

Fig. 3. Pebrinefree and Pebrine infected Cocoons of Antheraeamylitta (Daba TV).

Pebrine free

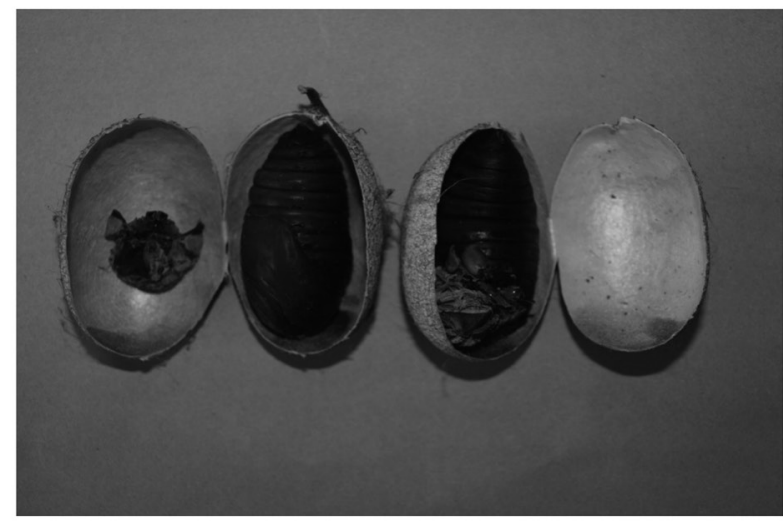

Pebrine infected

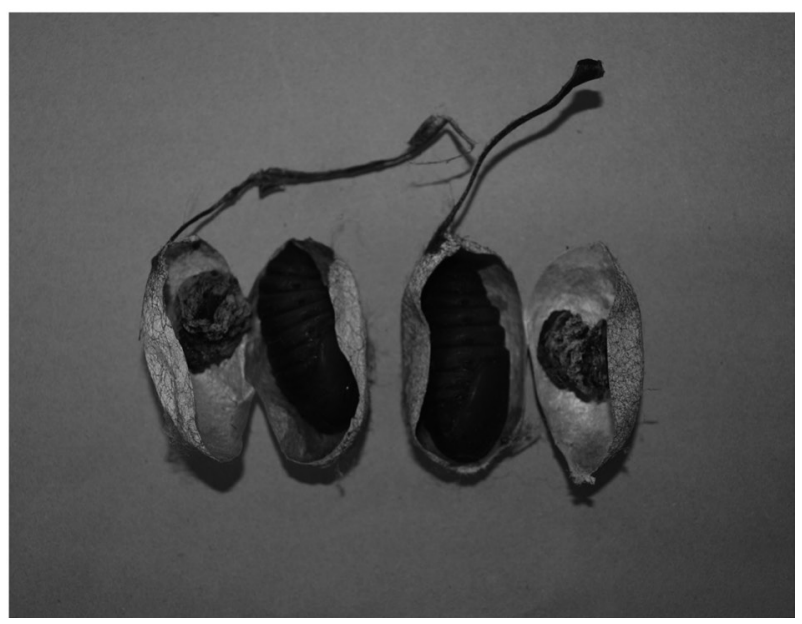

Fig. 4. Pebrine free and Pebrine infected pupae of Tasar silkworm, Antheraeamylitta (Daba TV).

silkworm. The spores multiply in number; the digestive juices act on the spores, the polar filament is extruded and soon becomes detached from the spore. Soon these develop into globular planonts, which invade the haemocoel, intestine, gonads, malphigian tubules and silk glands by rapid proliferation. In the various body tissues of the silkworm, they gradually increase in size and become meronts / schizonts by draining the cytoplasmic contents of the host and finally becoming a sporont. The mode of infection and transmission of the spores are mainly through oral, cuticular and ovarial pathways (Kramer, 1976). In the ovarial pathway, the pathogen is incorporated into the egg within the female reproductive tract and the progeny from such females are also infected. The rate of disease transmission and degree of infection in the offspring is directly related to the intensity of infection in the mother moth (Griyaghey and Sengupta, 1989; Talukdar, 1995).

Some of the microsporidia show transovarial transmission and some are not (Fujiware, 1980; Fujiware, 1984; Ananthalakshmi et al., 1994; Nageshwara Rao et al., 2004). Most of the species are highly virulent and mortality caused by them also varies. No silkworm race is reported to be completely immune to pebrine. Spores of Nosema sp. can be detected at any stage of life cycle in Tasar silkworm (Sharan et al., 1992) and are different in size, shape and pathogenicity (Shabir Ahmad Bhat et al., 2009). The present experiment is an attempt to study in detail the pathogenic effects of Pebrine on tasar silkworm, Antheraea mylitta D (Daba TV).

The silk protein fibroin is fibrous in nature, forming the main silk filament content, while sericin is a sticky coating substance between the layers of fibroin. Thus, the quality of cocoons depends both on sericin and fibrin which are controlled by atmospheric conditions (Shamitha and Rao, 2006). The sericin content as being the deciding factor in the quality of the cocoon and raw silk reeled was reported by Singhvi and Bose (1991). However, filament length and quality of the shell are based on the fibroin content. The present studies provides insight into the damaging effects of the Pebrine infection in the larval and cocoon stages resulting in poor quality of silk and identifies the need to designate proper measures to prevent the disease. 


\section{Material and Methods}

\section{Rearing of Tasar silkworm}

The trivoltine tasar silkworm, Antherae amylitta (Daba TV) were reared in outdoor under normal condition on a diet of fresh Terminalia arjuna plantation, at the experimental garden of Kakatiya University at $26-33^{\circ} \mathrm{C}$ and $37-50 \%$ R.H and $13 \mathrm{~L}+11 \mathrm{D}$ photoperiodic condition and, about two dfls were reared during December 2011-February 2012. Another batch of Pebrine free larvae (2 DFLs- disease free layings) of tasar silkworm, Antheraea mylitta (Daba TV) were collected from neighbouring forest patches for comparative analysis (Fig. 5).

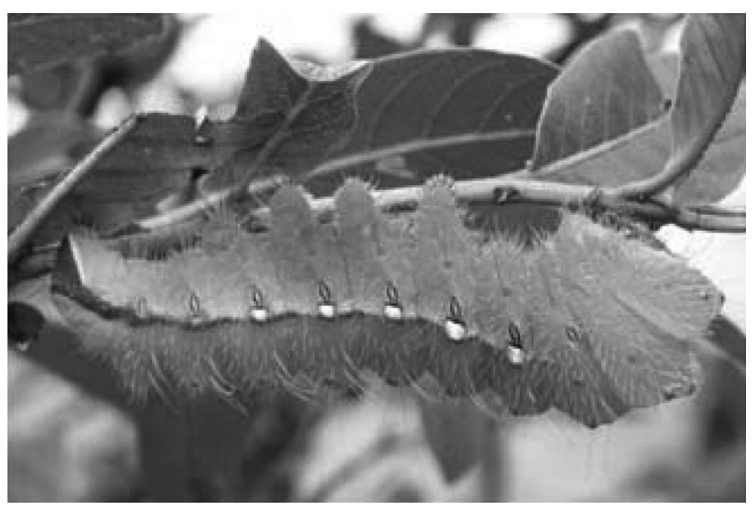

Fig. 5. V-instar larvae of Antheraeamylitta(Daba TV) Pebrine-free larvae.

\section{Symptoms of Pebrine}

The incidence of Pebrine disease in the rearing lot was identified by the symptoms in the early larval stages. The appearance of black spots on the body and unequal larval development are the most prominent symptoms of this disease. They exhibit poor appetite resulting into stunted growth and irregular moulting. The larvae detected with Pebrine infection are immediately removed and buried far away from the rearing site. The instar-wise larval mortality is presented in the results (Table 1).The larvae soon become pale and dull with wrinkled cuticle. As the larval stages advance, the appearance of black spots in the integument becomes more prominent, exhibiting melanosis.

\section{Identification of the disease}

The studies on silk gland were conducted by their collection from individual fifth instar larvae in a dissection tray containing normal saline. The dissected glands were weighed on Citizen Balance (Table 2) by removing any excess water. The infected silk glands (Fig. 6) along with posterior glands (Fig. 7) were spread on the slide and examined under microscope at 40X magnification for Nosema spores. The haemolymph was collected by puncturing the

Table 1. Instar-wise Average Temperature (C), Average Relative Humidity (\%) and Mortality due to Pebrine disease of Tasar silkworm, Antheraea mylitta (Daba TV)

\begin{tabular}{|c|c|c|c|c|c|c|}
\hline \multirow{2}{*}{ Instar } & Temparature ${ }^{\circ} \mathrm{C}$ & $\begin{array}{c}\text { Humidity } \\
(\%)\end{array}$ & Mortality & \multirow{(\%)}{*}{ Loss } & \multicolumn{2}{|c|}{ Larval life span } \\
\cline { 4 - 7 } & & & & & Pebrine free & Pebrine infected \\
\hline I & $33.02 \pm 0.61$ & $37.6 \pm 1.51$ & - & - & 4 & 5 \\
\hline II & $33.8 \pm 1.47$ & $39 \pm 2.30$ & 10 & 4 & 4 & 4 \\
\hline III & $33.05 \pm 3.64$ & $41.28 \pm 2.42$ & 51 & 20.4 & 6 & 7 \\
\hline IV & $26.67 \pm 0.51$ & $49.55 \pm 9.98$ & 62 & 24.8 & 7 & 43 \\
\hline V & $29.03 \pm 2.50$ & $45.43 \pm 6.76$ & 117 & 93.6 & 29 & 4 \\
\hline
\end{tabular}

The values are expressed in terms of Standard Error of the Mean. 
Table 2. Larval weight,Silk gland weight and \% Decrease in Pebrine- free and Pebrine infected V-instar Antheraea mylitta (Daba TV)

\begin{tabular}{|c|c|c|c|c|}
\hline SL.NO & $\begin{array}{c}\text { Anthereamylitta Drury, } \\
\text { (Daba TV) }\end{array}$ & $\begin{array}{c}\text { PEBRINE-firee of An- } \\
\text { thereamylitta Drury, } \\
\text { (Daba TV) }\end{array}$ & $\begin{array}{c}\text { PEBRINE-infected } \\
\text { Anthereamylitta Drury, } \\
\text { (Daba TV) }\end{array}$ & $\begin{array}{c}\text { Decrease } \\
(\%)\end{array}$ \\
\hline 1 & Larval weight & $22.48 \pm 1.54$ & $19.93 \pm 1.80$ & 11.34 \\
\hline 2 & Silk gland weight & $1.05 \pm 0.04$ & $0.40 \pm 0.26$ & 61.90 \\
\hline
\end{tabular}

The values are expressed in terms of Standard Error of the Mean.
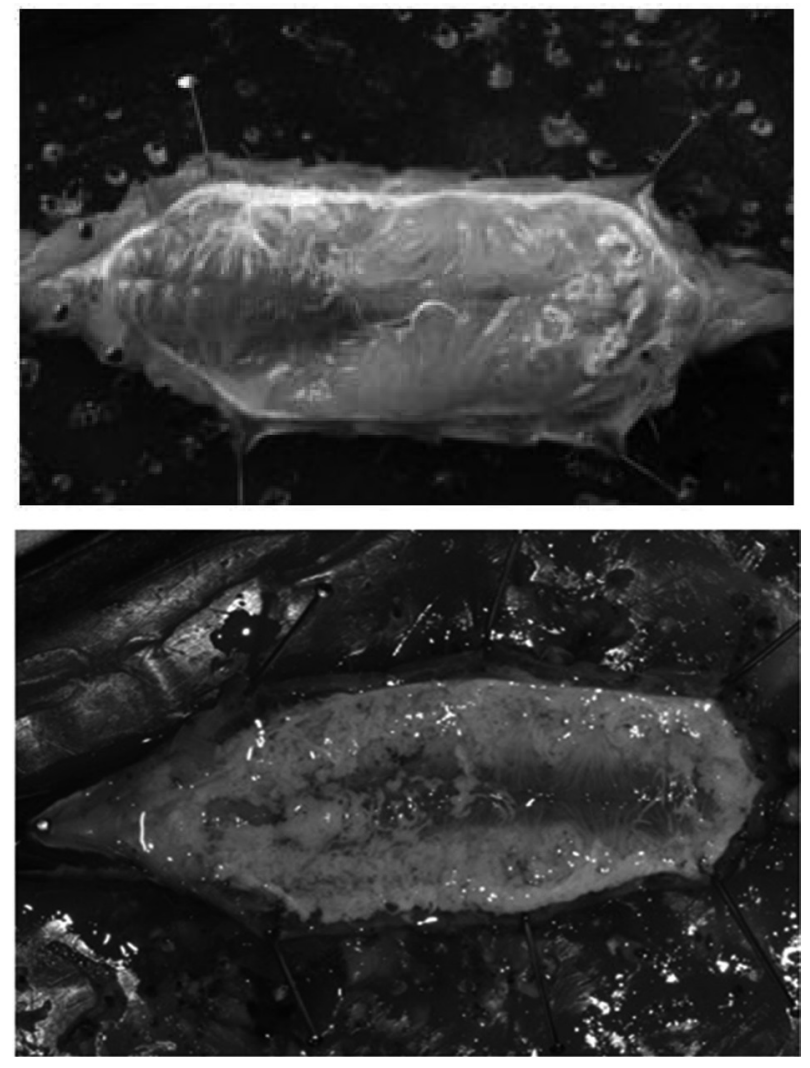

Fig. 6. Silk glands of Pebrine free and Pebrine infected (Nosemamylittensis) tasar silkworm. Antheraeamylitta (Daba TV).

last pair of legs of fifth instar larvae and smeared on a clean slide (Fig. 8) for examination under microscope at 40X magnification for Nosema spores.

A severely infected larva may die before spinning or it may spin a flimsy cocoon or spits and wastes the silk. However, a good number of infected worms have been allowed to spin for studying the post cocoon
(A) Healthy silk gland.

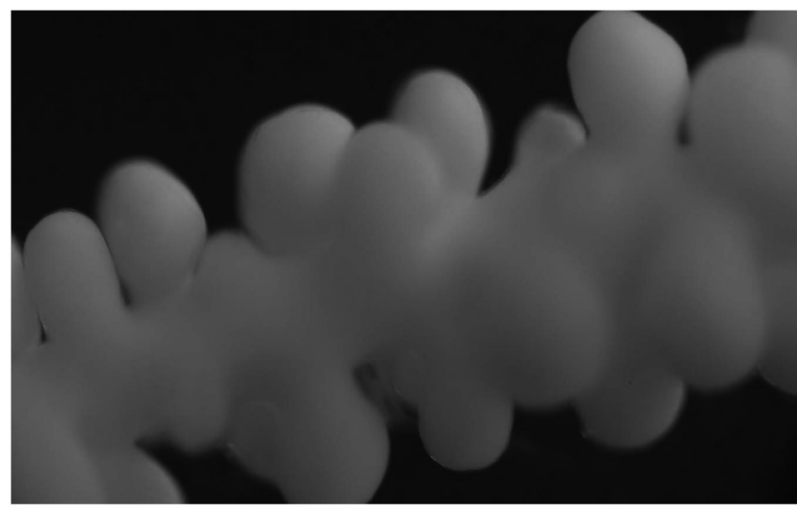

(B) Nosema infected Silk gland.

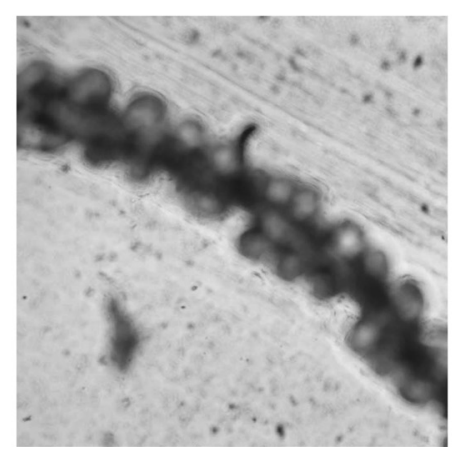

Fig. 7. A comparative diagram of Pebrine free and Nosemamylittensis (Pebrine) infected Posterior silk gland of Antheraeamylitta (Daba TV).

characters (Table 3). In the pupa, the abdominal area is soft and swollen and dark in colour. Black spots may be seen on the sides near the wing area. Sometimes the infected pupae do not show any symptoms. In order to detect the disease at pupal stage, the pupae were first washed with distilled water for two minutes, and then the lower half of the abdomen (gut) was placed in a 


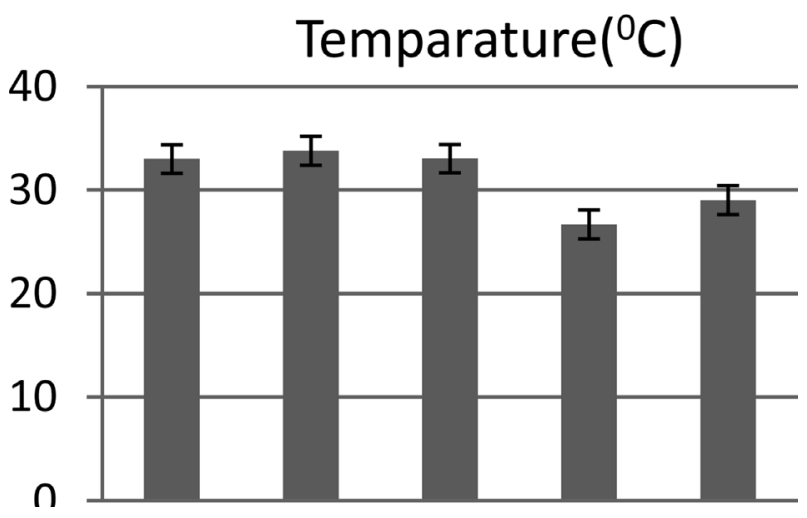

Fig. 8. Nosemamylittensis(Pebrine) spores in larval HaemolymphAntheraeamylitta(Daba TV).

clean mortar. The tissue was crushed and the smear examined under microscope at 40X magnification for Nosema spores (S.K. Sharan, et al, 1992).

\section{Evaluation of larval / cocoon parameters}

The larval, cocoon and post-cocoon parameters of Pebrine free and infected worms were measured as follows:

\section{Temperature $\left({ }^{\circ} \mathrm{C}\right)$ and relative humidity $(\%)$}

The optimum temperature and relative humidity for the tasar silkworm rearing are $25-30^{\circ} \mathrm{C}$ and $60-70 \%$ respectively. In the present study, the temperature and relative humidity were recorded with the help of lab thermometer and hygrometer respectively. The average of lowest and highest values taken and noted them instar-wise.

\section{Mortality}

The mortality was calculated by counting the number of worms dead and diseased due to microsporidian pathogen (Pebrine disease) during each instar by observing the symptoms and accordingly the percentage was calculated.

\section{The larval / pupalweight}

At the beginning of each instar, 10 healthy worms were selected at random from the rearing lot, which are feeding on the Terminali aarjuna plants for measurement of larval weight, taken from the day after hatching during the first instar to fifth instar. Larval weights were measured in an electronic Citizen balance (Model no: CG 203) in grams. The percent difference between Pebrine free and Pebrine infected worms was also calculated. The average weight $(\mathrm{g})$ of 5 randomly selected pupae was also taken.

Table 3. Cocoon parameters of Pebrine free and Pebrine infected tasar silkworm, Antheraea mylitta (Daba TV)

\begin{tabular}{|c|l|c|c|c|c|c|c|c|c|}
\hline $\begin{array}{c}\text { S. } \\
\text { no }\end{array}$ & Silkworm & $\begin{array}{c}\text { Cocoon } \\
\text { Weight } \\
\text { (grams) }\end{array}$ & $\begin{array}{c}\text { Shell } \\
\text { Weight } \\
\text { (grams) }\end{array}$ & $\begin{array}{c}\text { Shell } \\
\text { ratio } \\
(\%)\end{array}$ & $\begin{array}{c}\text { Pupal } \\
\text { eight } \\
\text { (grams) }\end{array}$ & $\begin{array}{c}\text { Reelability } \\
(\%)\end{array}$ & $\begin{array}{c}\text { Weight } \\
\text { of the } \\
\text { filament } \\
\text { (grams) }\end{array}$ & $\begin{array}{c}\text { Length } \\
\text { of the } \\
\text { Filament } \\
\text { (meters) }\end{array}$ & Denier \\
\hline 1 & $\begin{array}{c}\text { Pebrine- } \\
\text { free }\end{array}$ & $\begin{array}{c}9.50 \\
\pm 0.20\end{array}$ & $\begin{array}{c}1.25 \\
\pm 0.08\end{array}$ & 13.19 & $\begin{array}{c}8.16 \\
\pm 0.27\end{array}$ & 7.9 & 0.750 & 744 & 9.07 \\
\hline 2 & $\begin{array}{c}\text { Pebrine- } \\
\text { infected }\end{array}$ & $\begin{array}{c}4.47 \\
\pm 0.59\end{array}$ & $\begin{array}{c}0.27 \\
\pm 0.06\end{array}$ & 6.17 & $\begin{array}{c}4.12 \\
\pm 0.59\end{array}$ & 3.6 & 0.164 & 162 & 9.11 \\
\hline
\end{tabular}

The Values are expressed in terms of Standard Error of the Mean. 


\section{Silk gland weight:}

The average silk gland weight dissected from five $\mathrm{V}$ fifth instar larvae selected at random feeding on the $T$. Arjuna plants were taken and presented in the results.

\section{Length / weight of the filament}

Filament length was measured by using cocoon approvette. It has an axis around which four wooden sticks were arranged at equal distance with the circumference of $9 / 8$ meters. It is rotated with the help of a handle at one end. And to the other hand of the axis is a bell by which number of rotations was known. The number of rotations multiplied by the circumference gives the filament length.

Filament length $=9 / 8$ met X No. revolutions

The reeled silk weight measured with the electronic digital balance in grams.

\section{Shell Ratio (\%)}

The shell ratio is calculated by the following formula

$$
\text { Shell ratio }(\%)=\frac{\text { Shell Weight }}{\text { Cocoon Weight }} \times 100
$$

\section{Reelability (\%)}

The reelability of cocoons for economic reeling is the ease with which the cocoons yield the bave in reeling, which is called the reelability of cocoons. This is calculated by the following formula:

$$
\text { Reelability }(\%)=\frac{\text { Weight of the silk reeled }}{\text { Weight of the cocoons }} \times 100
$$

\section{Denier}

The difference in thickness of the size of the bave from beginning to the end is so gradual and minute in tasar cocoon that it does not interfere with the quality of the size of ultimate raw silk reeled. Denier is obtained by the following formula:

$$
\text { Denier }=\frac{\text { Weight of the silk reeled }}{\text { Length of the reeled }} \times 9000
$$

\section{Results}

\section{Temperature and Relative Humidity}

The instar wise average temperature and its standard deviation of Tasar silkworm Antheraea mylitta (Daba TV) rearing of 2011- 2012 were $33.02 \pm 0.61$ (S. D), $33.8 \pm 1.47$ (S. D), $33.05 \pm 3.64$ (S. D), $26.67 \pm 0.51$ (S. D) and $29.03 \pm 2.50$ (S. D) while that of rearing were I, II, III, IV and V instar respectively (Fig. 9)

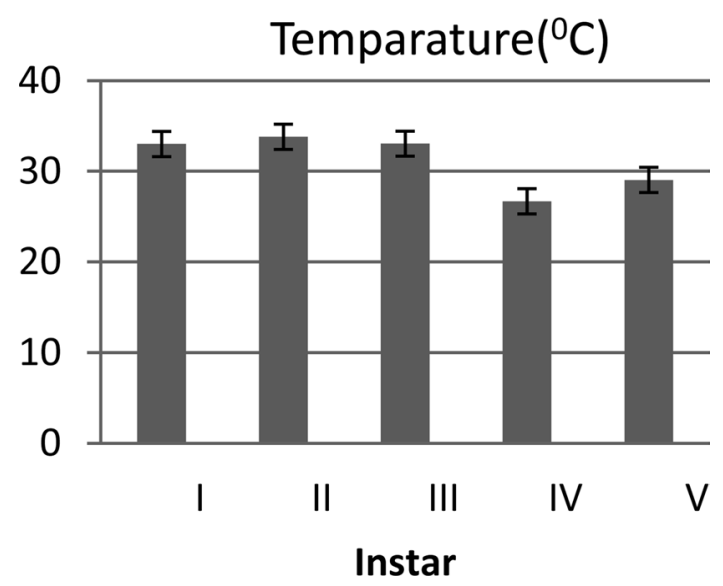

Fig. 9. Instar wise temperature $\left({ }^{\circ} \mathrm{C}\right)$ during the rearing of tasar silkworm, Antheraea mylitta (Daba TV).

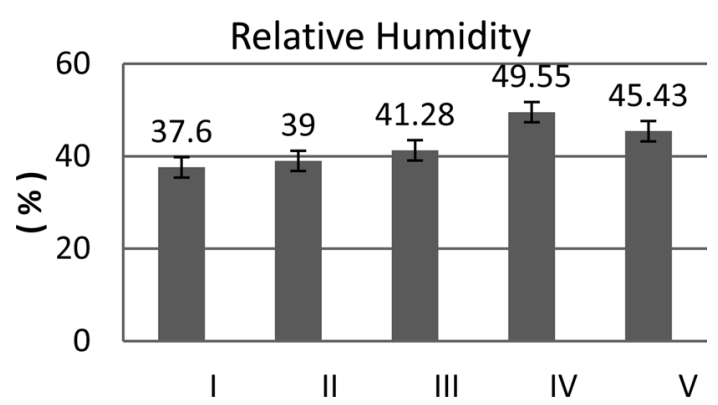

Fig. 10. Instar wise Relative humidity (\%) during the rearing of Tasar silkworm, Antheraea mylitta (Daba TV). 


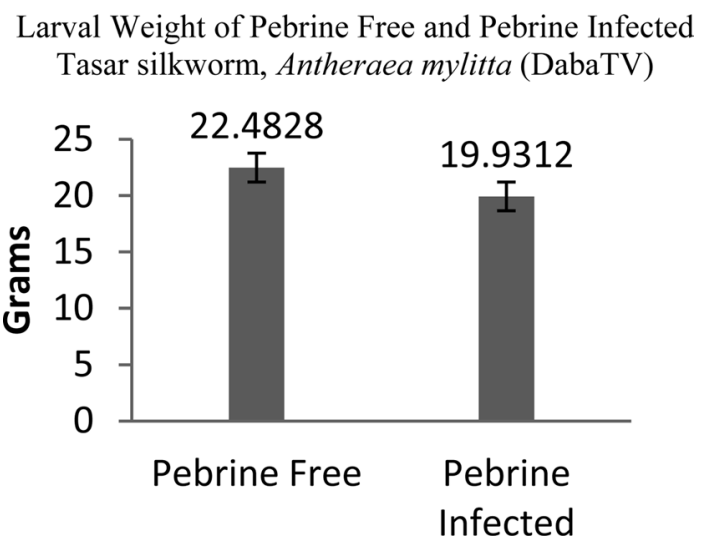

Fig. 11. Larval weight of Pebrine-Free and Pebrine infected Tasar silkworm, Antheraea mylitta (Daba TV).

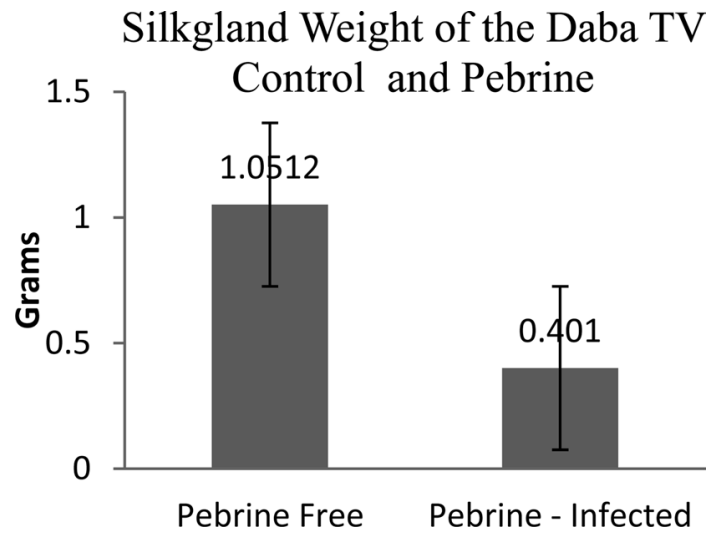

Fig. 12. Silk gland weight of Pebrine free and Pebrine infected Tasar silkworm, Antheraea mylitta (Daba TV).

The instar wise average Relative Humidity and its standard deviation of Antheraea mylitta (Daba TV) rearing were $37.6 \pm 1.51(\mathrm{~S} . \mathrm{D}), 39 \pm 2.30(\mathrm{~S}$. D), $41.28 \pm 2.42$ (S. D), $49.55 \pm 9.98$ (S. D) and $45.43 \pm 6.76$ (S. D) in the I, II, III, IV and V instars respectively (Fig. 10).

\section{Larval and silk gland weight}

The average larval weight and its standard deviation of Pebrine- free tasar silkworm, Antheraea mylitta Drury, was $22.48 \pm 1.54$ (S.D) while that of, Pebrine infected one was $19.93 \pm 1.80$ (S.D) (Fig. 11).

The average Silk gland weight and its standard

\section{Cocoon parameters of Antheraea mylitta (DabaTV)Control and Pebrine.}

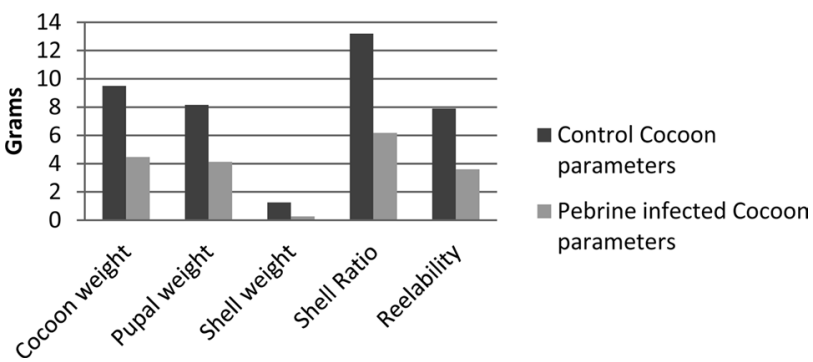

Fig. 13. Cocoon Parameters of Pebrine free and Pebrine infected tasar silkworm, Antheraea mylitta(Daba TV).

deviation of Pebrine free tasar silkworm, Antherae amylitta Drury, was $1.05 \pm 0.04$ (S.D) while that of Pebrine infected larva was $0.40 \pm 0.26$ (S.D) (Fig. 12).

\section{Post cocoon parameters}

The post-cocoon characters of Pebrine free and Pebrine infected tasar silkworm, Antheraea mylitta Drury (Daba TV), reared during the 2011-2012 include cocoon weight (gr), shell weight (gr), shell ratio (\%), Pupal weight, Reelability, weight of the filament, length of the filament and Denier which are: $9.50 \pm 0.20$ (S.D), $1.25 \pm 0.08$ (S.D), $13.19 \%, 8.16 \pm$ 0.27 (S.D), 7.9\%, 0.750 grams, 744 meters and 9.07 . while than that of Pebrine infected were $4.47 \pm 0.59$ (S.D), $0.27 \pm 0.06$ (S.D), 6.17\%, $4.12 \pm 0.59$ (S.D), 3.6\%. 0.164 grams, 162 meters and 9.11 respectively (Fig. 13).

\section{Discussion}

The etiology of Pebrine (Nosema bomycis Naegeli) dates back to mid19th century as an epidemic of silkworm, Bombyx mori, when it spread to all sericulture countries of Europe resulting in decline of silk production. From the earlier reports it is understood that in tropics Pebrine is commonly 
prevalent in Thailand, Cambodia, and Vietanam etc. Later, it has also spread to Indian sub-continent by late $19^{\text {th }}$ century. The disease has been noticed intermittently in silk crops during 1925-30, 194047, and 1991-92 as periodic outbreaks in several silk producing parts of our country (Chitra et al., 1975).

A report on Pebrine incidence in Thailand (Somsri, et al., 1991) in two generation of multivoltine race of Bombyx mori has shown normal oviposition but decreased hatching and high mortality were observed and subsequently, a decrease in number of egg laying and increase in number of dead eggs were found in the deformed wings moths.

There are also several reports on Nosema bombycis, a highly virulent micro-organism, damaging the silkworm crops in Japan and other Asian countries. A detailed morphology and life cycle of Nosema assamensis, pathogenic microsporidian causing pebrine in Antheraea assamensis, confined to Assam, India has revealed the ultra structural details of the virulent spore by Scanning Election Microscope (S. Chakrabarti, 2009).

Earlier, tasar mortality due to Pebrine was reported by Jolly in 1968. Studies on larval mortality by instar in varied seasons by Mishra (1992) and Pebrine control measures by feeding of Benomyl, Carbestine, Bngrad in specified dosages from second instar was cited by Sinha (2005). The present study calls for a remedial measure to prevent this epizootic disease which causes alarming loss to tasar culture which has a direct relevance to tribal employment.

From the results it is observed that mortality due to Pebrine was apparent from $2^{\text {nd }}$ instar and gradually increased in $3^{\text {rd }}, 4^{\text {th }}$ instars and reached its peak in the fifth instar, which may be due to the manifestation of virulent parasitic microsporidian, Nosema mylittensis, in the late instars. This is in corroboration with the earlier studies that the mortality of A.mylitta larvae accelerated from $3^{\text {rd }}$ instar onwards, with increasing intensity of disease symptoms (Sen et al., 1969).

It is found that there is a significant loss of larval body weight with a corresponding and drastic decrease in the silk gland weight of the Pebrine infected tasar silkworms. It is in good agreement with the view that Dabaecorace recorded highest concentration of silk protein in its silk glands compared to other ecoraces studied (Lokesh et al., 2012). The higher consumption of dietary food and corresponding higher metabolic activities leads to better conversion of leaf proteins in to silk proteins.

The post-cocoon parameters have revealed that the weights of the cocoon, shell and filament have substantially decreased in the Pebrine-infected cocoons. The decrease in the weight and length of the silk filament is extreme. From the literature it is inferred that the quantitative as well as qualitative nutrition is highly essential for sericigenous insects to maintain important physiological status and lack of such nutrition in the tasar silkworm might have extended its larval span (Chapman, 1998; Behmer, 2006; Kumar et al., 2010). This is in agreement with the present studies which show an instar-wise extension of larval life span, more so in the fifth instar (Table 1). The potential fitness and maturity attainment is only possible when the larva obtain adequate amount of nutrients in a required balance, the deficiency of which leads to longer larval duration, lesser ERR and cocoon yield, which are inter-related (Reddy et al., 2012). It is also supported by the view that the larvae can survive better on getting the required nutrition by improving defense system, which also shorten its larval span and lessen the chance of exposure to the diseases, pests and pathogens (Baylis, 1991; Ojala et al., 2005).

From the present studies it is evident that this dreadful disease which may be transmitted through the egg and ingestion of the contaminated food by the larvae / origination of the pathogen from infected eggs laid by infected mother moths / its pre-existence in rearing site as spores / wild insects naturally infected with Nosema mylittensis can be prevented by selecting the disease free laying before rearing; burying away of diseased larvae and silkworm waste; disinfection of rearing equipment and dusting 5\% bleaching powder with slaked lime (Singh, 2005).

In the present investigation, it is revealed that the 
pupal weight in Pebrine infected larva has shown high reduction, which may lead to low fecundity. A recent study of $N$. bombycis on the impact of egg production and disease transmission has revealed that fecundity, hatchability and diseased population are dependent on spores in the female larvae (Jyothi and Patil, 2008). The main characteristic of microsporidian infection is its long lasting and chronic effect to the host. As the fecundity is dependent on the reserves of nutritious substances accumulated in the larva, before pupation and silk moths do not consume any food (Verber and Jassic, 1961), they mainly develop in the fat bodies of the host and the infection causes depletion of nutritive reserves resulting in less fecundity in females (Arm strong and Bass, 1986).

This study suggests that there is an urgent need to develop an efficient method to control the disease. Although medium temperature and relative humidity can stimulate the pathogen (Dasgupta, 1950), some studies have shown that high temperature and relative humidity can cause minimum incidence of Pebrine (Devaiah, 1975). Nosema mylittensisis a well known entomopathogen of pebrine and loss incurred due to this disease varies from $35-40 \%$ (Sahay et al., 2000). The results of the study by Singh G.P. et al. (2005) indicated that bleaching powder, slaked lime and formalin were effective in the inactivation of both Antheraea mylitta cytoplasmic polyhedrosis virus (AmCPV) and spores of $N$. mylittensis, while a recent report has indicated the indoor rearing performed at lower temperature and disinfected conditions can minimize the Pebrine to some extent (Shiva Kumar and Shamitha, 2009).

The origin of Nosema along with other microsporidians which infect a wide range of eukaryotes causing severe diseases in immune-compromised humans and losses to apiaries, fisheries and silk farms has been traced back to fungal relatedness (Patrick et al., 1998). In 2003, Japanese scientists have conducted several identification tests of Nosema $s p$., mainly by Flourescent antibody techniques, ELISA, Latex adhesion tests, analyses of rRNA genes by sequencing and PCR and unveiled the phylogeny of several silkworm microsporidians (Kawarabata, 2003). The position of Nosema sp in evolutionary relationships among microsporidian lineages was also depicted by Patrick et al., in 2004. The virulence of Nosema bombycis is established by genomic studies (Yoshinori, 2009), however, the molecular studies towards the origin, phylogeny and detailed morphology of Nosema mylittensis is still an unexplored area so that a disease resistant strain of A.mylitta with genetic adaptability needs to be evolved using modern biological tools.

The Pebrine infection is found to be one of the major constraints in tasar culture, which causes heavy loss to the crops. Hence, the prevention and management of this disease is a crucial factor for high yield of cocoons and quality silk. As there is a persistent demand for tasar silk in both domestic and international fronts, and on the other hand, the tasar production base is totally tribal community dependent, there is an immediate urge to prevent the disease incidence in the food plant and the silkworms by quick remedial measures and ensure quality production of the silk.

\section{Acknowledgement}

The authors are grateful to Department of Biotechnology (DBT), New Delhi, for providing funds to carry out the present work under MRP grant (BT/PR13300/PBD/19/206/2009)

\section{References}

Ananthalakshmi KVV, Fujiwara T, Datta RK (1994) First report on the isolation of three microsporidians (Nosema sp.) from the silkworm, Bombyx.mori.L India. Indian Journal of Sericulture 2, 146-48.

Armstrong E, Bass LK (1986) Effect of infection by Nosema whitei on mating frequency and fecundity of Tribolium castaneum. J Invertebr Pathol 47, 310-316. Baylis M, Pierce NE (1991) The effect of host-plant quality 
on the survival of larvae and oviposition by adults of an ant-tended lycaenid butterfly, Jalmenus evagoras. EcolEntomol16, 1-9.

Behmer ST (2006) Insect Dietary Needs: Plants as Food for Insects .Plant and Crop Sci 12, 1-4.

Chapman RF (1998) The insect structure and function. Cambridge university press, Cambridge.

Chitra C, Karanth NGK, Vasantharajan VN (1975)

Diseases of the mulberry silkworm Bombyxmori L. J Sci Indust Res 34, 386-401.

Dasgupta MR (1950) Monographs on cottage industries, No. 1, Disease of Silkworms Govt. Indian press, Calcutta202.

Devaiah R, Krishnaswami S (1975) Observed on the seasonal incidence of Pebrine disease on the silkworm Bombyx mori. Indian J Sericulture 14, 27-30.

Fujiwara T (1980) Three microsporidians (Nosema spp.) from the silkworm, Bombyx mori. Journal of Sericulture Science Japan 49, 229-236.

Fujiwara T (1984) A Pleistophora like microsporidian isolated from the silkworm, Bombyx mori. Journal of Sericulture Science Japan 53, 398-402.

Griyaghey UP, Sengupta K (1989) Studies on the transmission of Nosema sp., in tropical tasar silkworm, Antheraeamylitta D. Sericologia 29, 383-387.

Jolly MS (1968) Central Tasar Research Station, Ranchi. Tasar scientific brochure 4,1-31.

Jyothi NB, Patil CS (2008) Development of Nosema bombycis naegeli in the ovary, its impact on egg production and disease transmission in silkworm Bombyx mori L. Sericologia 48(1), 37-45.

Kawarabata Takeshi (2003) Biology of Microsporidians infecting the silkworm, Bombyx mori. Sericologia 72, 1-32.

Kramer (1976) Microsporidia \& Micro sporidiasis,1999, Murray Wittner \& Louis M Weiss, 90.

Kumar R, Manohar Reddy R, Sinha PS, Tirkey J, Singh MK, Prasad BC (2010) Impact of leguminous biomulching on soil properties, leaf yield and cocoon productivity of tropical tasar culture under rainfed condition. J Entomol 7, 219-226.

Lokesh G, Putkho Paul Pao, Madhusudhan KN, Kar PK, Srivastava AK, Sinha MK, Manohar Reddy R,
Muniswamy Reddy PM, Prasad BC (2012) Study of Phenotypic Variability in Silk Gland Characters in Three Ecoraces of Tropical Tasar Silkworm Antheraea mylitta Drury. Asian Journal of Animal and Veterinary Advances 7, 80-84.

Mishra CSK (1992) Larval mortality of Indian tasar silkworm (Antheraea mylitta.D) (Saturnidae) due to Pebrine infection. Journal of the Lepidopterists society 46(2), 106-109.

NageswaraRao S, Muthulakshmi M, Kanginakudru S, Nagaraju J (2004) Phylogenetic relationships of three new microsporidian isolates from the silkworm, Bombyx mori. Journal of Invertebrate Pathology 86, 87-95.

Ojala K, Tiitto RJ, Lindstrom L, Mappes J (2005) Diet affects the immune defense and life-history traits of anarctiid moth Parasemia plantaginis. Evolut Ecol Res 7, 1153-1170.

Pasteur L (1870) Etudessur la maladie des vers a soie. Gauthier-Villars, Paris Tome I, 322, Tome II, 327.

Patrick J Keeling, Claudio H Slamovits (2004) Botany Department, Canadian Institute for Advanced Research, University of British Columbia, Vancouver, British Columbia, Canada Simplicity and Complexity of microsporidian Genomes. Eukaryotic cell 3(6), 13631369.

Patrick J Keeling, Geoff I Fadden Mc (1998) Origins of microsporidia. Trends In Microbiology 6(1), 19.

Rath SS, Prasad BC, Sinha BR (2003) Food utilization efficiency in fifth instar larvae of Antheraea mylitta (Lepidoptera: Saturniidae) infected with Nosema sp. and its effect on reproductive potential and silk production. Journal of Invertebrate Pathology 83, 1-9.

Reddy R Manohar, Charan RupeshRao K, Mohan Angadi BS, Sivaprasad V (2012) Commercial Prospective of Lagerstroemia parviflora (Roxb) as Choice Food Plant of Tropical Tasar Silkworm, Antheraea mylitta(Drury). Int J Res Chem Environ 2, 70-73.

Reddy RM, Sinha MK, Prasad BC (2010) Breeding perspective for silk yield and quality in Indian tropical tasar silkworm, Antheraea mylitta Drury (Lepidoptera: Saturniidae). J Applied Sci 10, 1902-1909.

Sahay DN, Roy DK, Sahay A (2000) Diseases of Tropical Tasar Silkworm, Antheraea mylitta D., Symptoms 
and Control Measures In: Lessons on Tropical Tasar, Thangavelu, K. Central Tasar Research and Training Institute, Piska-Nagri, Ranchi, pp 104.

Singhvi NR, Bose PC (1991) Sericin a deciding factor for the quality of cocoons and raw silk. Indian Silk, 26-28.

Singh GS, Vishwakarma SR, Sathyanarayana N (2005) Recent trends in tropical tasar silkworm rearing technology and future strategy, proceedings of National work shop on recent advances in tasar culture. 37- 48.

Satadai Chakrabarti, Buddhadeb Manna (2009) Parasitology Research Unit, Department of Zoology, University of Calcutta 700019 India, Studies on Ultra structure and life cycle of Nosema assamensis (Protozoa : Microsporida), A parasite of Muga silkworm, Antheraea assamensis. Indian Journal of Sericulture 48 (1), 60-67.

Sen SK, Jolly MS, Jammi TR (1969) Diseases of Tasar silkworm A.mylitta (Saturniidae ). Indian J Sericulture 8, 11-14.

Shamitha G, Purushotham Rao A (2006) Studies on the filament of tasar silkworm, Antheraea mylitta. D (Andhra localecorace). Current Science 90(12), 1667-1670.

Shabir Ahmad Bhat, Ifat Bashir, Afifa S Kamili (2009) Microsporidiosis of silkworm, Bombyx mori L. (Lepidoptera- bombycidae): A review. African Journal of Agricultural Research Vol 4 (13), 1519-1523.

Sharan SK, Bansal AK, Shukla RM, Thangavelu K (1992) A new method of detection of pebrine disease in tasar silkmoth, Antheraea mylitta Drury (Saturnidae). Journal of Research on the Lepidoptera 31(1-2), 12-15pp.

Shiva Kumar G, Shamitha G (2009) Larval mortality in Antheraea mylitta. D (Daba TV) due to Pebrine disease in the Outdoor and Indoor Conditions. Proceedings of the National Seminar Biotechnology in Life Sciences Current Trends and Developments, 167-172.

Singh GP, Alok Sahay Roy DK, Sahay DN (2005) Efficacy of Disinfectants against Cytoplasmic Polyhedrosis Virus and Microsporidia of Tasar Silkworm, Antheraea mylitta $\mathrm{D}$. International Journal of Industrial Entomology 10(1), 69-72.

Somsri Kantarattanakul, Bangarn Nakaum (1991) Studies on pebrine disease in the silkworm, Bombyx mori L. I. Pathogenicity in the multivoltine strains, Proceedings of the 29th Kasetsart University: Plant Science, Kasetsart Univ., Bangkok (Thailand).- Bangkok (Thailand), p. 369-380.

Talukdar JN (1995) Symptoms of a microsporidian infection in the muga silkworm, Antheraea assamensis., effect on egg production and hatching. Sericologia 35, 55-60.

Verber J, Jassic J (1961) Microsporidian as a factor in reducing fecundity in insects. J Insect pathol 3, 103-111.

Yoshinori Hatakeyama, Yukita Sato, Koichi Murata, Masayoshi Yukawa, Hidetoshi Iwano (2009) Search for and detection of specific DNA fragments in high - and low - virulent strains of Nosema bombycis (Microsporida: Nosematidae). Journal of Insect Biotechnology and Sericology 78, 17-21 